\title{
Buckwheat Honey Attenuates Carbon Tetrachloride-Induced Liver and DNA Damage in Mice
}

\author{
Ni Cheng, ${ }^{1,2}$ Liming Wu, ${ }^{3}$ Jianbin Zheng, ${ }^{2}$ and Wei Cao ${ }^{1,2}$ \\ ${ }^{1}$ Department of Food Science and Engineering, School of Chemical Engineering, Northwest University, 229 North TaiBai Road, \\ Xian 710069, China \\ ${ }^{2}$ Shaanxi Provincial Key Lab of Electroanalytical Chemistry, Institute of Analytical Science, Northwest University, \\ 229 North TaiBai Road, Xian 710069, China \\ ${ }^{3}$ Institute of Apicultural Research, Chinese Academy of Agricultural Science, Beijing 100093, China
}

Correspondence should be addressed to Jianbin Zheng; zhengjb@nwu.edu.cn and Wei Cao; caowei@nwu.edu.cn

Received 1 March 2015; Revised 14 May 2015; Accepted 4 June 2015

Academic Editor: Abbas A. Mahdi

Copyright (C) $2015 \mathrm{Ni}$ Cheng et al. This is an open access article distributed under the Creative Commons Attribution License, which permits unrestricted use, distribution, and reproduction in any medium, provided the original work is properly cited.

\begin{abstract}
Buckwheat honey, which is widely consumed in China, has a characteristic dark color. The objective of this study was to investigate the protective effects of buckwheat honey on liver and DNA damage induced by carbon tetrachloride in mice. The results revealed that buckwheat honey had high total phenolic content, and rutin, hesperetin, and p-coumaric acid were the main phenolic compounds present. Buckwheat honey possesses super DPPH radical scavenging activity and strong ferric reducing antioxidant power. Administration of buckwheat honey for 10 weeks significantly inhibited serum lipoprotein oxidation and increased serum oxygen radical absorbance capacity. Moreover, buckwheat honey significantly inhibited aspartate aminotransferase and alanine aminotransferase activities, which are enhanced by carbon tetrachloride. Hepatic malondialdehyde decreased and hepatic antioxidant enzymes (superoxide dismutase and glutathione peroxidase) increased in the presence of buckwheat honey. In a comet assay, lymphocyte DNA damage induced by carbon tetrachloride was significantly inhibited by buckwheat honey. Therefore, buckwheat honey has a hepatoprotective effect and inhibits DNA damage, activities that are primarily attributable to its high antioxidant capacity.
\end{abstract}

\section{Introduction}

The liver plays important roles in metabolism, secretion, excretion, and biotransformation. In China, where liver disease is common, there are approximately 130 million individuals with hepatitis $\mathrm{B}$ virus, which may contribute to chronic hepatitis, cirrhosis, or liver cancer. Therefore, there has been an increasing interest in the treatment and prevention of liver disease. Oxidative stress, which is involved in the pathogenesis of liver diseases, leads to hepatic damage [1]. Antioxidants such as silymarin, tocopherol, and betaine have desirable effects in patients with liver disease [2-4].

Carbon tetrachloride $\left(\mathrm{CCl}_{4}\right)$ is one of the most widely used toxins for the experimental induction of liver damage in laboratory animals. The hepatotoxicity of $\mathrm{CCl}_{4}$ stems from reductive dehalogenation products, such as trichloromethyl $\left(\mathrm{CCl}_{3}{ }^{\circ}\right)$ and trichloromethyl peroxyl $\left(\mathrm{CCl}_{3} \mathrm{O}_{2}{ }^{\circ}\right)$ radicals [5], which can bind to proteins and lipids or remove a hydrogen atom from an unsaturated lipid, thereby initiating lipid peroxidation and contributing to liver damage [6]. In recent years, numerous studies have shown that polyphenol extract from natural products with high scavenging radical activity and strong reducing power could attenuate $\mathrm{CCl}_{4}$-induced liver damage [7-9]. Our previous studies have also proven that bee pollen extract rich in phenolic compounds increases antioxidant potential in mice and protects against $\mathrm{CCl}_{4}$ induced liver damage [10].

Buckwheat (Fagopyrum esculentum Moench), which is cultivated in several Asian and European counties, is an important source of nectar and pollen for bees. Buckwheat honey has a characteristic dark color and its antioxidant activity has been studied for more than 10 years. Pasini et al. [11] reported that there are 20 phenolic acids in buckwheat honey, including $p$-hydroxybenzoic and $p$-coumaric acids. 
Phenolic antioxidants from buckwheat honey are bioavailable and increase the antioxidant activity of plasma. Gheldof et al. [12] reported that the serum antioxidant capacity determined by oxygen radical absorbance capacity (ORAC) was significantly increased following the consumption of buckwheat honey in water. However, in vitro serum lipoprotein oxidation and thiobarbituric acid reactive substances (TBARS) were not significantly affected following a single consumption of buckwheat honey. Therefore, long-term studies on oxidative stress-induced illnesses are necessary to investigate whether buckwheat honey has antioxidant-related health benefits. In this study, we assessed the antioxidant capacity of buckwheat honey in mice and evaluated its protection potential for attenuating $\mathrm{CCl}_{4}$-induced liver and DNA damage.

\section{Materials and Methods}

2.1. Materials. Buckwheat honey was obtained from Shaanxi Bee Master Co., Ltd. (Xi'an, China). The pollen frequency (Fagopyrum esculentum) was approximately 61\%. Buckwheat honey samples were stored at $4^{\circ} \mathrm{C}$.

2.2. Chemicals and Reagents. Fluorescein disodium (FL), 1,1-diphenyl-2-picrylhydrazyl radical 2,2-diphenyl-1-(2,4,6trinitrophenyl)hydrazyl (DPPH), 2,2' -azobis(2-amidinopropane)dihydrochloride (AAPH), dimethyl sulfoxide (DMSO), Trolox, and silymarin were obtained from SigmaAldrich (Steinheim, Germany). Agarose was purchased from BioRad (Hercules, CA, USA). Diagnostic kits for aspartate aminotransferase (AST), alanine aminotransferase (ALT), malondialdehyde (MDA), superoxide dismutase (SOD), glutathione peroxidase (GSH-Px), and protein were obtained from Nanjing Jiancheng Bioengineering Institute (Nanjing, China). Lymphocyte separation medium was purchased from Tianjin Hao Yang Biological Manufacture Co., Ltd. $\mathrm{CCl}_{4}$, peanut oil, and other chemicals were acquired from Tianjin Kemiou Chemical Reagent Co. (Tianjin, China).

\subsection{Antioxidant Assays}

2.3.1. Total Phenolic Content (TPC) and HPLC Analysis. We used a modified Folin-Ciocalteu method to determine TPC in buckwheat honey [13]. Briefly, $0.2 \mathrm{mg}$ of buckwheat honey was mixed with $1.0 \mathrm{~mL}$ of Folin-Ciocalteu reagent, allowed to stand at room temperature for $5 \mathrm{~min}$, and mixed with $5 \mathrm{~mL}$ of $1 \mathrm{M} \mathrm{Na}_{2} \mathrm{CO}_{3}$. An hour later, absorbance was measured at $760 \mathrm{~nm}$. TPC was expressed as the gallic acid equivalents per gram of buckwheat honey (mg GA/g).

The contents of individual phenols in buckwheat honey were estimated by HPLC-DAD analysis as proposed by Liang et al. [14]. An Agilent 1100 HPLC system (Agilent Technologies Deutschland, Waldbronn) equipped with a vacuum degasser, a quaternary solvent delivery pump, a manual chromatographic valve, a thermostated column compartment, and a diode-array detector (Agilent, Palo Alto, CA, USA) was used. The column was a Zorbax SB-C18 column $(150 \mathrm{~mm} \times$ $4.6 \mathrm{~mm}, 5.0 \mu \mathrm{m})$. The mobile phase adopted was methanol (A) and $0.15 \%$ aqueous acetic acid solution (B) (v/v) using a linear gradient elution of $5-15 \% \mathrm{~A}$ at $0-10 \mathrm{~min}, 15-35 \%$ $\mathrm{A}$ at $10-15 \mathrm{~min}, 35-55 \% \mathrm{~A}$ at $15-20 \mathrm{~min}, 55-65 \% \mathrm{~A}$ at $20-$ $25 \mathrm{~min}, 65-80 \% \mathrm{~A}$ at $25-30 \mathrm{~min}$, and $80 \% \mathrm{~A}$ at $30-35 \mathrm{~min}$. The injected volume was $5 \mu \mathrm{L}$, and flow rate was $1.0 \mathrm{~mL} / \mathrm{min}$. The column was operated at $30^{\circ} \mathrm{C}$. The diode-array detector was performed at $360 \mathrm{~nm}$.

2.3.2. DPPH Radical Scavenging Activity. DPPH radical scavenging activity of buckwheat honey was assessed according to the method proposed by Wang et al. [15]. Briefly, different volumes of buckwheat honey $(0.2 \mathrm{~g} / \mathrm{mL})$ were mixed with $4.0 \mathrm{~mL}$ of $0.1 \mathrm{mM}$ DPPH radical solution. After adjusting the total volume to $10 \mathrm{~mL}$, the mixture was mixed well and allowed to stand at room temperature for $30 \mathrm{~min}$ in the dark. Absorbance was measured at $517 \mathrm{~nm}$. The DPPH radical scavenging activity was expressed as Trolox equivalents per gram of buckwheat honey (mg Trolox/g).

2.3.3. Ferrous Ion-Chelating Activity. The ferrous ionchelating activity of buckwheat honey was measured by the method reported by Singh and Rajini with some modifications [16]. In this experiment, $50 \mu \mathrm{L}$ of buckwheat honey $(0.2 \mathrm{~g} / \mathrm{mL})$ was mixed with $50 \mu \mathrm{L}$ of $1 \mathrm{mM}$ iron vitriol and $20 \mu \mathrm{L}$ of $1 \mathrm{mM}$ ferrozine. The total volume was adjusted to $1 \mathrm{~mL}$ with methanol and incubated at room temperature for $10 \mathrm{~min}$. The absorbance of the ferrozine- $\mathrm{Fe}^{2+}$ complex was measured at $562 \mathrm{~nm}$. Ferrous ion-chelating activity was expressed as $\mathrm{Na}_{2}$ EDTA equivalents per gram of buckwheat honey ( $\mathrm{mg} \mathrm{Na}{ }_{2}$ EDTA/g).

\subsubsection{Ferric Reducing Antioxidant Power (FRAP). FRAP of} buckwheat honey was assessed by the method reported by Benzie and Strain [17]. Buckwheat honey $(0.3 \mathrm{~mL}$ at $0.2 \mathrm{mg} / \mathrm{mL})$ was mixed with $4.0 \mathrm{~mL}$ of FRAP reagent $(2.5 \mathrm{~mL}$ of $10 \mathrm{mM}$ TPTZ solution in $40 \mathrm{mM} \mathrm{HCl}$ with $2.5 \mathrm{~mL}$ of $20 \mathrm{mM} \mathrm{FeCl}_{3} ; 25 \mathrm{~mL}$ of $0.3 \mathrm{M}$ acetate buffer, $\mathrm{pH} 3.6$ ), mixed well and incubated at $37^{\circ} \mathrm{C}$ for $4 \mathrm{~min}$. Absorbance was measured at $593 \mathrm{~nm}$. FRAP was expressed as Trolox equivalents per gram of buckwheat honey (mg Trolox/g).

\subsubsection{Animals and Study Design}

(1) Animals. Male Kunming mice (18-22 g) were obtained from Xian Jiaotong University and housed in cages with six mice per cage. The animal ethical approval communication number is SCXK 2012-003. The animal experiments followed the guidelines and regulations of the State Committee of Science and Technology of the People's Republic of China.

After acclimatization to laboratory conditions for $7 \mathrm{~d}$, the mice were randomly divided into four groups (12 mice/group). Control mice and $\mathrm{CCl}_{4}$-treated mice were administered distilled water via gavage at $0.22 \mathrm{~mL} / 10 \mathrm{~g} \mathrm{BW}$, twice daily for 10 weeks. According to the doses of honey and silymarin reported by Cheng et al. [18], the mice were administered $0.22 \mathrm{~g} / 10 \mathrm{~g}$ BW of buckwheat honey and $0.5 \mathrm{mg} / 10 \mathrm{~g}$ BW of silymarin via gavage twice daily for 10 weeks. To investigate the serum antioxidant capacity after administration of buckwheat honey, the mice in the control 
and honey groups were bled by cardiac puncture $2 \mathrm{~h}$ after the last administration. The blood samples were centrifuged at $3000 \mathrm{rpm}$ for $15 \mathrm{~min}$ to obtain serum. The serum was used for serum lipoprotein oxidation and ORAC assays.

To investigate the protective effects of buckwheat honey on $\mathrm{CCl}_{4}$-induced liver damage, all mice were continuously intragastrically administered distilled water, buckwheat honey, and silymarin for the next week. Two hours following the last administration, all mice (except control mice) were administered a $\mathrm{CCl}_{4} /$ peanut oil mixture $(0.2: 100$, intraperitoneally, $0.1 \mathrm{~mL} / 10 \mathrm{~g} \mathrm{BW}$ ); control mice received only peanut oil. Subsequently, the animals were fasted for $16 \mathrm{~h}$ and bled by cardiac puncture. Half of the blood samples were transferred to anticoagulant tubes for separating lymphocytes, and the other half were transferred to ordinary centrifuge tubes for serum collection.

(2) Serum Lipoprotein Oxidation. Serum lipoprotein oxidation was assessed by the method reported by Regnström et al. [19]. Serum samples from control and honey groups were diluted with phosphate buffer $\left(10.1 \mathrm{mM} \mathrm{Na} \mathrm{HPO}_{4}, 1.8 \mathrm{Mm}\right.$ $\mathrm{KH}_{2} \mathrm{PO}_{4}, 27 \mathrm{mM} \mathrm{KCl}$, and $138 \mathrm{mM} \mathrm{NaCl}$ ) to $0.5 \%$. Copper ions at $12 \mu \mathrm{mol} / \mathrm{L}$ were added to the diluted serum samples. Oxidation kinetics was determined at $234 \mathrm{~nm}$ every 20 minutes at $37^{\circ} \mathrm{C}$. Diluted serum samples without copper were used as blanks. The area under the oxidation curve (AUC) was plotted and the percentage inhibition of serum lipoprotein oxidation was calculated according to the following equation:

$$
\text { Inhibition }(\%)=\frac{\left(\mathrm{AUC}_{\text {control }}-\mathrm{AUC}_{\text {honey }}\right)}{\mathrm{AUC}_{\text {control }}} \times 100
$$

where $\mathrm{AUC}_{\text {control }}$ is the area under the oxidation curve for the control group serum samples and $\mathrm{AUC}_{\text {honey }}$ is the area under the oxidation curve for the honey group serum samples.

(3) ORAC Assay. The ORAC assay was performed in 96well plates and measured in a multifunctional plate reader (Infinite M200Pro, Switzerland) [20]. Serum samples from the control and honey groups were used in this assay. Analyses were performed in $75 \mathrm{mM}$ sodium phosphate buffer $(\mathrm{pH}=7.4)$ at $37^{\circ} \mathrm{C}$. The excitation wavelength was $485 \mathrm{~nm}$ and the emission wavelength was $535 \mathrm{~nm}$. FL was used as the substrate and AAPH was used for the production of peroxyl radicals. Briefly, $50 \mu \mathrm{L}$ of $78 \mathrm{nM}$ FL and $50 \mu \mathrm{L}$ of $1 \%$ serum were transferred to 96 -well plates. The blank consisted of $50 \mu \mathrm{L}$ of phosphate buffer instead of serum. The mixture was preincubated at $37^{\circ} \mathrm{C}$ for $30 \mathrm{~min}$ before rapidly adding $25 \mu \mathrm{L}$ of $221 \mathrm{mM}$ AAPH solution. The plate was automatically shaken prior to each reading. Fluorescence was measured every 5 minutes. The assay was performed in triplicate, and the results were expressed as inhibition of the area under the curve (AUC) according to the following equation:

$$
\begin{aligned}
\text { Inhibition }(\%)= & \frac{\left(\text { net } \mathrm{AUC}_{\text {honey }}-\text { net } \mathrm{AUC}_{\text {control }}\right)}{\text { net } \mathrm{AUC}_{\text {control }}} \\
& \times 100,
\end{aligned}
$$

where net $\mathrm{AUC}_{\text {control }}=\mathrm{AUC}_{\text {control }}-\mathrm{AUC}_{\text {blank }}$; net $\mathrm{AUC}_{\text {honey }}=\mathrm{AUC}_{\text {honey }}-\mathrm{AUC}_{\text {blank }}$.

(4) Comet Assay. The comet assay is the preferred technique for detecting DNA damage in single cells. In this study, lymphocytes isolated from control mice, $\mathrm{CCl}_{4}$-treated mice, and honey mice were analyzed by the comet assay to assess the protective effects of buckwheat honey on $\mathrm{CCl}_{4}$-induced DNA damage. Lymphocytes from silymarin mice were set as the positive reference. Following the methods proposed by Singh et al. [21] with slight modifications, lymphocytes were suspended in $0.15 \mathrm{M}$ of phosphate buffer $(\mathrm{pH} 7.4)$ at a density of $1 \times 10^{5} / \mathrm{mL}$. After fixing the lymphocytes on slides, the slides were immersed in lysis buffer $(2.5 \mathrm{M} \mathrm{NaCl}, 100 \mathrm{mM}$ EDTA, 1\% N-lauroylsarcosine at pH 10, $10 \mathrm{mM}$ Tris- $\mathrm{HCl}, 1 \%$ Triton X-100, and 10\% dimethyl sulfoxide (DMSO)) for $2 \mathrm{~h}$. Subsequently, the slides were immersed in electrophoresis buffer (1 mM EDTA and $300 \mathrm{mM} \mathrm{NaOH}, \mathrm{pH}$ 13) for DNA unwinding. After $30 \mathrm{~min}$, electrophoresis was run at $25 \mathrm{~V}$ (300 mA) for $20 \mathrm{~min}$ in the dark. All slides were treated with ethidium bromide and observed under a fluorescence microscope (Nikon 027012; Nikon, Tokyo, Japan). The results were scored and analyzed using an automated analysis system of the Comet Assay Software Project (CASP). At least 50 cells were scored from each slide. The degree of DNA damage was scored by determining the percentage of DNA in the tail (tail DNA \%) and olive tail moment (OTM), defined as the fraction of tail DNA multiplied by the distance between the means of the head and tail:

$$
\begin{aligned}
\text { tail DNA\% }= & \left(\frac{\text { tail DNA }}{(\text { head DNA }+ \text { tail DNA })}\right) \times 100, \\
\text { OTM }= & (\text { tail DNA } \%) \\
& \times(\text { tail mean }- \text { head mean }) .
\end{aligned}
$$

(5) Assessment of Liver Function. Serum was obtained following the centrifugation of blood samples at room temperature for $20 \mathrm{~min}$ at 3,000 rpm. Serum ALT and AST values were measured using commercially available diagnostic kits.

(6) Determination of MDA, SOD, and GSH-Px Activities. After the animals were sacrificed, livers were immediately excised. With the exception of a portion of the left lobe to be used for histopathological examination, the livers were homogenized in phosphate buffer $(50 \mathrm{mM}, \mathrm{pH} 7.4)$ and centrifuged at 2,500 rpm for $20 \mathrm{~min}$ at $4^{\circ} \mathrm{C}$. The MDA content, $\mathrm{SOD}$, and GSH-Px activities along with protein levels in the supernatant were estimated according to commercially available diagnostic kits.

(7) Histopathological Examinations. A left lobe portion of the liver was incubated for $24 \mathrm{~h}$ in $10 \%$ neutral formalin solution. Based on standard procedures, we obtained $5 \mu \mathrm{m}$ sections for histopathological studies using hematoxylin and eosin (H\&E) staining.

2.4. Statistical Analysis. We analyzed the data in triplicate using SAS software version 8.1 (SAS Institute, Cary, NC, 
TABle 1: Phenolic compounds ( $\mathrm{mg} / \mathrm{kg}$ ) and TPC (mg GA/g) of buckwheat honeys.

\begin{tabular}{lc}
\hline Phenolic compounds & Concentration \\
\hline Gallic acid & $2.02 \pm 0.52$ \\
Protocatechuic acid & $1.09 \pm 0.34$ \\
Chlorogenic acid & $0.56 \pm 0.07$ \\
-Coumaric acid & $12.52 \pm 1.92$ \\
Rutin & $35.94 \pm 3.76$ \\
Quercetin & $1.97 \pm 0.09$ \\
Hesperetin & $23.76 \pm 0.31$ \\
Galangin & $2.38 \pm 0.18$ \\
TPC & $2.039 \pm 0.03$ \\
\hline
\end{tabular}

Results presented in the table are expressed as means \pm standard deviation (SD) for 3 replications.

TABLE 2: Antioxidant activities of buckwheat honey in vitro.

\begin{tabular}{lc}
\hline Antioxidant index & Results \\
\hline DPPH radical scavenging activity & $0.304 \pm 0.02(\mathrm{mg} \mathrm{Trolox} / \mathrm{g})$ \\
Ferrous ion-chelating activity & $0.479 \pm 0.01\left(\mathrm{mg} \mathrm{Na}_{2} \mathrm{EDTA} / \mathrm{g}\right)$ \\
Ferric reducing antioxidant power & $0.355 \pm 0.05(\mathrm{mg} \mathrm{Trolox} / \mathrm{g})$ \\
\hline
\end{tabular}

The results presented in the table were expressed as the mean values \pm standard deviation (SD) for 3 replications.

USA). Tukey's posttest was used to assess statistical significance $(P$ value $<0.05)$.

\section{Results}

3.1. Antioxidant Assay of Buckwheat Honey. To study the antioxidant activity, the TPC and individual phenolic compounds of buckwheat honey were determined, and the results are shown in Table 1 and Figure 1. The TPC of buckwheat honey was $2.04 \mathrm{mg} \mathrm{GA} / \mathrm{g}$. Four phenolic acids and four flavones were identified in buckwheat honey. Rutin, the most abundant phenolic compound, was measured at $35.94 \mathrm{mg} / \mathrm{kg}$, followed by hesperetin $(23.76 \mathrm{mg} / \mathrm{kg})$ and $p$-coumaric acid $(12.52 \mathrm{mg} / \mathrm{kg})$.

The results of antioxidant activities of buckwheat honey in vitro are shown in Table 2. The DPPH radical scavenging activity is a widely used method to evaluate antioxidant capacity. The DPPH radical scavenging activity of buckwheat honey was $0.304 \mathrm{mg}$ Trolox/g. The ferrous ion-chelating activity of buckwheat honey was $0.479 \mathrm{mg} \mathrm{Na}{ }_{2} \mathrm{EDTA} / \mathrm{g}$. The FRAP assay is often used to determine the antioxidant properties of foods based on their electron-donating capacity [22]. As shown in Table 2, the FRAP value of buckwheat honey was $0.355 \mathrm{mg}$ Trolox $/ \mathrm{g}$, which is comparable to the values obtained in jujube honey, but lower than those obtained in cacao farm honey, mangrove honey, citrus honey, and a coconut grove honey in Mexico (48-152 mg Trolox/100 g) [23].

3.2. Buckwheat Honey Increased Serum Antioxidant Capacity in Mice. The administration of buckwheat honey $(0.22 \mathrm{~g} / 10 \mathrm{~g}$ BW, twice daily) for 10 weeks resulted in the inhibition

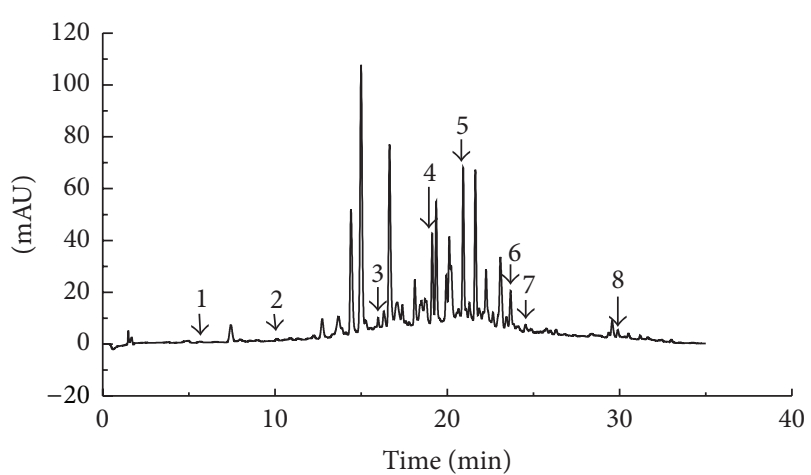

FIGURE 1: Chromatogram of the buckwheat honey using HPLCDAD. Peaks: 1 = gallic acid; $2=$ protocatechuic acid; $3=$ chlorogenic acid; $4=p$-coumaric acid; $5=$ rutin; $6=$ quercetin; $7=$ hesperetin; 8 $=$ galangin.

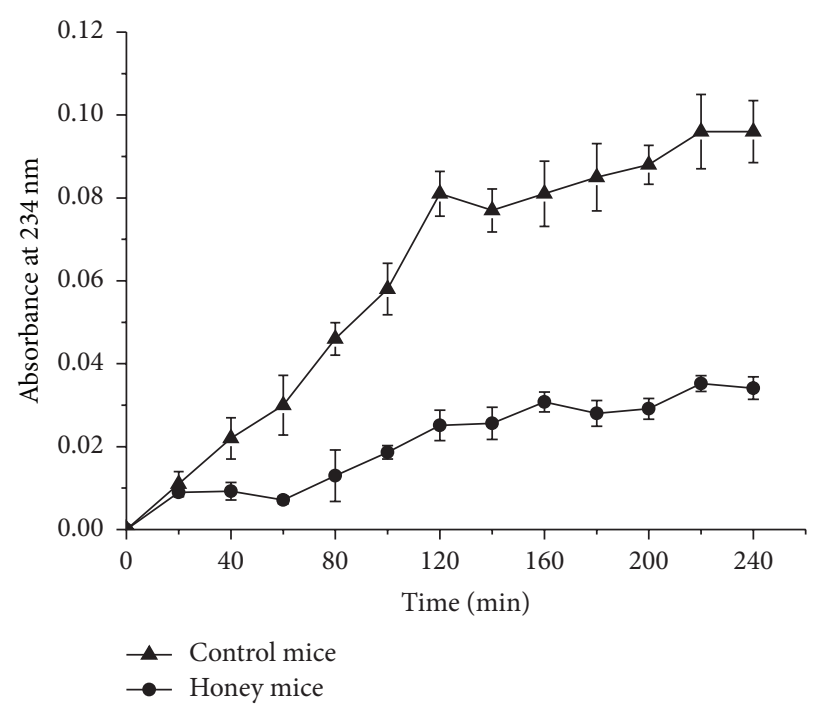

FIGURE 2: Effects of buckwheat honey on serum lipoprotein oxidation (absorbance values had been adjusted for the initial absorbance reading). Control mice were administered distilled water via gavage. Honey mice were administered buckwheat honey $(0.22 \mathrm{~g} / 10 \mathrm{~g}$ BW, twice daily for 10 weeks) via gavage.

of serum lipoprotein oxidation. Buckwheat honey inhibited serum lipoprotein oxidation by $65.71 \%$ (Figure 2). Serum ORAC is another method for measuring serum antioxidant capacity. As described in Figure 3, serum from honey-treated mice had a relatively high ORAC value, whereas serum from control mice had a relatively low ORAC value $(27.19 \%$ lower than the former).

3.3. Buckwheat Honey Attenuated DNA Damage Induced by Carbon Tetrachloride. The protective effect of buckwheat honey on $\mathrm{CCl}_{4}$-induced damage is shown in Figure 4. Based on the picture of lymphocytes in the $\mathrm{CCl}_{4}$-treated group, a significant increase in the tail length of comet was observed. However, the lymphocyte from the mice administered honey and silymarin showed a similar decrease in the tail length of 


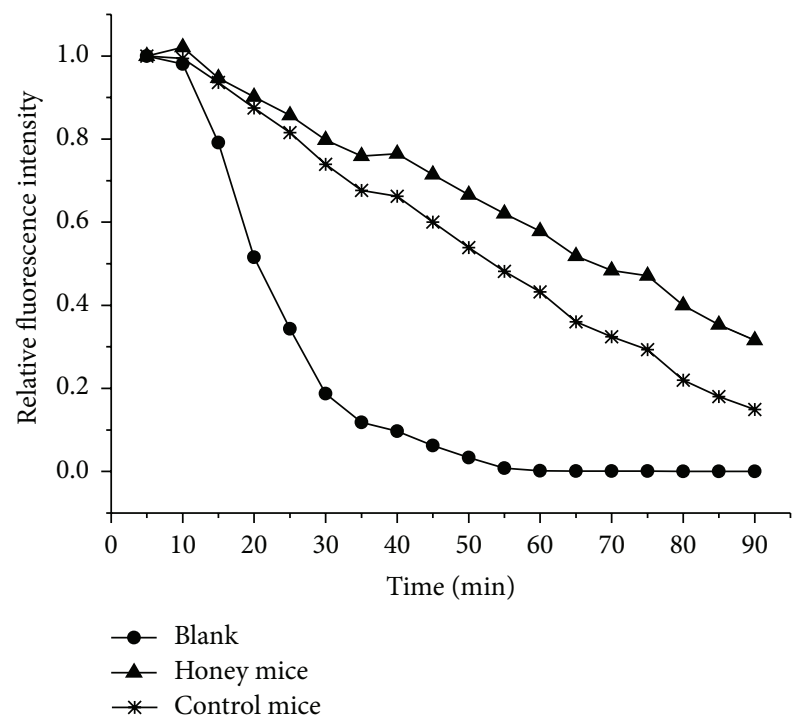

FIGURE 3: Effects of buckwheat honey on serum oxygen radical absorbance capacity (ORAC). Control mice were administered distilled water via gavage. Honey mice were administered buckwheat honey $(0.22 \mathrm{~g} / 10 \mathrm{~g}$ BW, twice daily for 10 weeks $)$ via gavage. In the blank, PBS was used instead of serum.

comet. As shown in Figures 4(b) and 4(c), a similar variation was presented in mean tail DNA and OTM. The mean tail DNA and OTM in the $\mathrm{CCl}_{4}$-treated group were $30.91 \%$ and $53.03 \%$, respectively, whereas the mean tail DNA and OTM in the control group were $11.76 \%$ and $5.21 \%$, respectively. Therefore, significant increases in the mean tail DNA and OTM of lymphocytes were associated with $\mathrm{CCl}_{4}$ exposure $(P<0.05)$. Interestingly, pretreatment with buckwheat honey $(0.22 \mathrm{~g} / 10 \mathrm{~g}$ BW, twice daily) for 11 weeks decreased lymphocyte damage significantly $(P<0.05)$. Silymarin, as a positive reference, had super protective effect on DNA damage induced by $\mathrm{CCl}_{4}$.

\subsection{Buckwheat Honey Protected the Liver from Carbon} Tetrachloride-Induced Damage. Serum ALT and AST activities were determined in this study and the results are shown in Figure 5. In the $\mathrm{CCl}_{4}$-treated group, serum ALT and AST activities were 170.68 and $55.01 \mathrm{U} / \mathrm{L}$, which were $15 \mathrm{x}$ and $1.52 \mathrm{x}$ higher than those of the control group, respectively $(P<0.05)$. In the honey and silymarin groups, serum ALT and AST activities were 11.12 and $27.77 \mathrm{U} / \mathrm{L}$ and 12.43 and 25.96 U/L, respectively. There were no significant differences in the hepatic enzyme activities between the control, honey, and silymarin groups. Therefore, buckwheat honey treatment ( $0.22 \mathrm{~g} / 10 \mathrm{~g}$ BW, twice daily) for 11 weeks inhibited an increase in serum ALT and AST activity.

Hepatic MDA levels and GSH-Px and SOD activities were monitored in this study and the results are shown in Figure 6. A $54.90 \%$ increase of hepatic MDA was obtained in the $\mathrm{CCl}_{4}$-treated group relative to the control mice. Pretreatment with buckwheat honey $(0.22 \mathrm{~g} / 10 \mathrm{~g}$ BW, twice daily) and silymarin $(0.5 \mathrm{mg} / 10 \mathrm{~g} \mathrm{BW}$, twice daily) for 11 weeks significantly decreased hepatic MDA levels in the $\mathrm{CCl}_{4}$-treated mice
$(P<0.05)$ (Figure 6(a)). The activities of GSH-Px and SOD in $\mathrm{CCl}_{4}$-treated mice decreased significantly compared to the control mice $(P<0.05$; Figure $6(\mathrm{~b}))$. Interestingly, pretreatment with buckwheat honey and silymarin significantly inhibited the decrease in GSH-Px and SOD activities induced by $\mathrm{CCl}_{4}(P<0.05)$.

The histological observations supported the results obtained from the enzyme assays. Liver sections from control mice showed regular cellular morphology (Figure 7(a)). However, liver sections from $\mathrm{CCl}_{4}$-treated mice revealed extensive liver damage characterized by severe hepatocellular hydropic degeneration and necrosis around the central vein, dilated sinusoidal spaces, inflammatory cell infiltration, and ballooning degeneration (Figure 7(b)). Surprisingly, pretreatment with buckwheat honey remarkably ameliorated the hypertrophy of hepatocytes, inflammatory cell infiltration, ballooning degeneration, and dilated sinusoidal spaces (Figure $7(\mathrm{c})$ ). The protective effect of buckwheat honey was similar to silymarin (Figure $7(\mathrm{~d})$ ).

\section{Discussion}

Phenolic compounds are present in plants and food products, including honey. Phenolic compounds possess powerful antioxidant capacity by acting as hydrogen donors to free radicals and as electron donors to metal ions [22]. According to previous studies, phenolic compounds are the main contributor to the antioxidant activity of honey. Moreover, the darker the honey, the stronger its antioxidant capability. Buckwheat honey is deemed the darkest honey in China. Therefore, a higher value of TPC (2.04 mg GA/g) was acquired in this study, which was significantly higher than that of seven honey samples from Slovenia, which ranged from $44.8 \mathrm{mg}$ $\mathrm{GA} / \mathrm{kg}$ in acacia honey to $241.4 \mathrm{mg} \mathrm{GA} / \mathrm{kg}$ in fir honey [24]. Because phenolic hydroxyl can donate a hydrogen atom to reduce free radicals [25], the DPPH radical scavenging activity of buckwheat honey was higher than that reported in black locust honey $(0.3 \mathrm{mmol}$ Trolox $/ \mathrm{kg})$, goldenrod honey (0.2 mmol Trolox $/ \mathrm{kg})$, rapeseed honey ( $0.4 \mathrm{mmol}$ Trolox $/ \mathrm{kg})$, and heather honey $(0.6 \mathrm{mmol}$ Trolox $/ \mathrm{kg})$ [26]. The ferrous ion-chelating activity represents another index of antioxidant activity in bioactive compounds because divalent transition metal ions play important roles in oxidation, such as by contributing to the formation of hydroxyl radicals and hydroperoxides via the Fenton reaction [27]. The ferrous ion-chelating activity of buckwheat honey was $0.479 \mathrm{mg} \mathrm{Na}_{2} \mathrm{EDTA} / \mathrm{g}$, approximately 10x higher than that of jujube honey (37.59$53.04 \mathrm{mg} \mathrm{Na}{ }_{2}$ EDTA/kg) [18]. The metal-chelating potential is strongly dependent on the arrangement of hydroxyls and carbonyl groups around the molecule [25]. Flavonoids such as rutin and hesperetin have been identified in buckwheat honey as the main phenolic compounds. Therefore, it is not difficult to understand why buckwheat honey has a high ferrous ionchelating activity.

To investigate whether buckwheat honey could increase the antioxidant capacity of the mice, $\mathrm{Cu}^{2+}$-induced oxidation of serum lipoprotein was determined. This method provides an indication of diene formation in lipoprotein fatty acids 


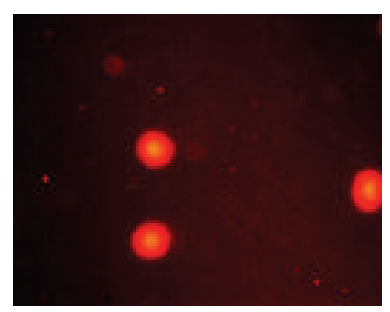

Control

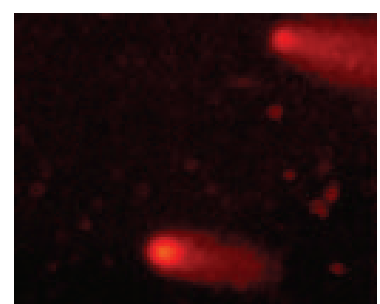

$\mathrm{CCl}_{4}$

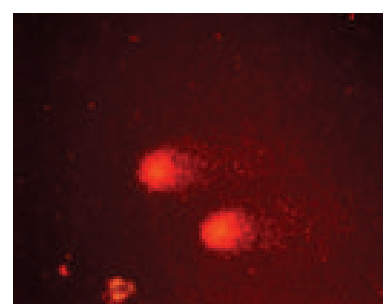

Honey $+\mathrm{CCl}_{4}$

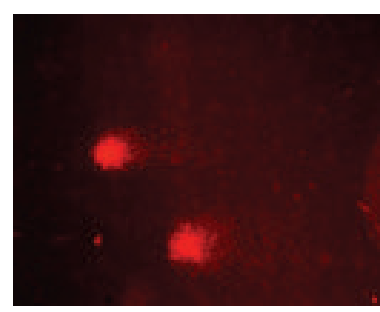

Silymarin $+\mathrm{CCl}_{4}$

(a)

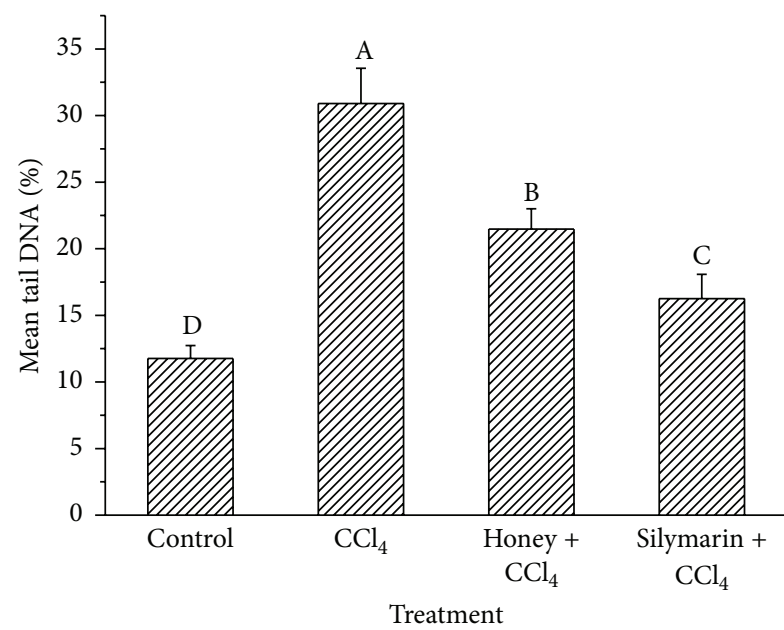

(b)

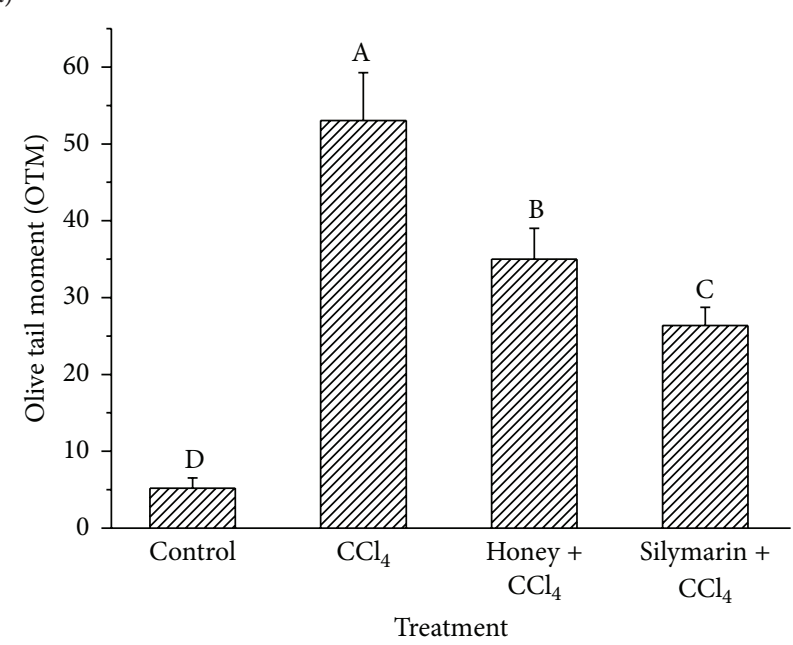

(c)

FIGURE 4: Effects of buckwheat honey on mice lymphocyte DNA damage induced by $\mathrm{CCl}_{4}$ ((a) picture of lymphocyte DNA damage; (b) mean tail DNA\%; (c): olive tail moment). Control: lymphocytes from control mice; $\mathrm{CCl}_{4}$ : lymphocytes from $\mathrm{CCl}_{4}$-treated mice; honey + $\mathrm{CCl}_{4}$ : lymphocytes from mice administered buckwheat honey $(0.22 \mathrm{~g} / 10 \mathrm{~g} \mathrm{BW})$ twice daily for 11 weeks prior to $\mathrm{CCl}_{4}$; silymarin $+\mathrm{CCl}_{4}$ : lymphocytes from mice administered silymarin $(0.5 \mathrm{mg} / 10 \mathrm{~g} \mathrm{BW})$ twice daily for 11 weeks prior to $\mathrm{CCl}_{4}$.

when exposed to $\mathrm{Cu}^{2+}$. Diene formation is assessed by measuring changes in absorbance at $234 \mathrm{~nm}$. High absorbance values correspond to diene formation as a result of serum lipoprotein oxidation, and low absorbance values correspond to inhibition of serum lipoprotein oxidation and, consequently, to high antioxidant activity [28]. The administration of buckwheat honey remarkably inhibited serum lipoprotein oxidation in this study. Phenolic compounds present in buckwheat honey inhibit oxidation of serum lipoproteins by acting as free radical scavengers or as metal-chelating agents [20]. Antioxidants are often added to foods to prevent the radical chain reactions of oxidation, and they act by inhibiting the initiation and propagation step, leading to termination of the reaction and a delay in the oxidation process $[25,29]$. Therefore, buckwheat honey significantly inhibited the $\mathrm{Cu}^{2+}$-induced oxidation of serum lipoprotein and increased the antioxidant capacity of mice. Serum ORAC is another method for measuring serum antioxidant capacity. This method, which incorporates FL as the fluorescent probe, is commonly used in biological samples and foods. The ORAC method is based on the inhibition of peroxyl-radicalinduced oxidation initiated by the thermal decomposition of AAPH [20]. FL blocks the peroxyl-radical chain reaction process by donating hydrogen protons, thereby reducing the fluorescence intensity. Antioxidants can inhibit the decrease in fluorescence intensity by scavenging AAPH or by donating hydrogen protons, thereby blocking the free radical chain reaction [30]. Accordingly, buckwheat honey administered to mice for 10 weeks at $0.22 \mathrm{~g} / 10 \mathrm{~g}$ BW increased the serum antioxidant activity.

Intraperitoneal administration of $\mathrm{CCl}_{4}$ is a classic method used to induce oxidation and liver damage $[7,8]$. Metabolites of $\mathrm{CCl}_{4}$ include highly reactive free radicals, which initiate the chain reaction of lipid peroxidation, thereby affecting polyunsaturated fatty acids and phospholipids [31]. Lipid peroxidation affects the permeability of the mitochondria, endoplasmic reticulum, and plasma membranes, resulting in leakage of hepatic enzymes in the blood. Serum ALT and AST activities have been confirmed to be the most sensitive indicator of $\mathrm{CCl}_{4}$-induced liver damage. Therefore, serum ALT and AST activities in the $\mathrm{CCl}_{4}$-treated group were significantly higher than those of the control group. Interestingly, pretreatment with buckwheat honey inhibited the increase of serum ALT and AST activities induced by $\mathrm{CCl}_{4}$. With increasing serum ALT and AST activities as a result of $\mathrm{CCl}_{4}$-induced damage, lipid peroxidation products (e.g., MDA) accumulate in hepatic cells. Therefore, hepatic MDA levels were monitored in this study. As shown in Figure 6(a), 


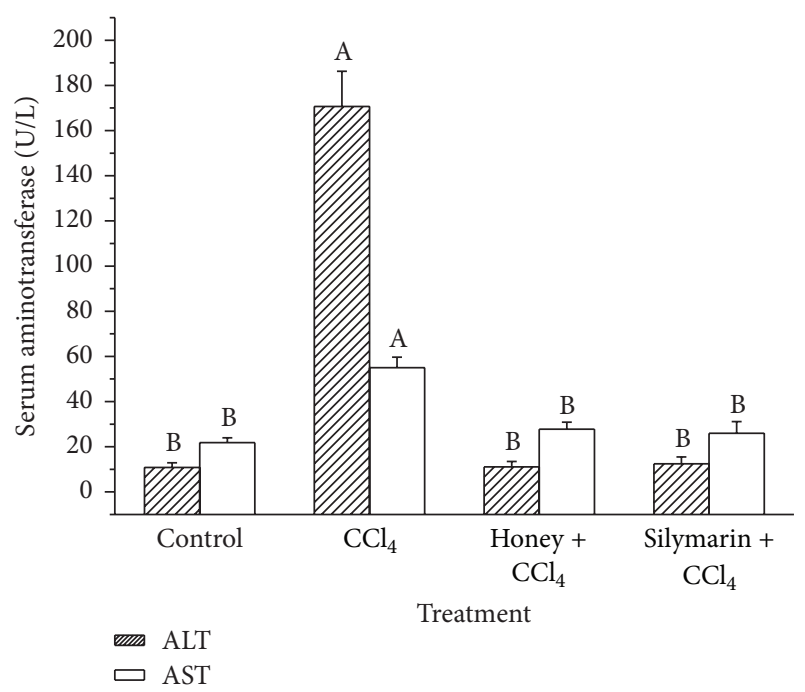

Figure 5: Effects of buckwheat honey on serum ALT and AST activities. Different lower case letters represent significant differences $(P<0.05)$. Mice in "control": distilled water plus peanut oil; mice in " $\mathrm{CCl}_{4}$ ": distilled water plus $\mathrm{CCl}_{4}$; mice in "honey $+\mathrm{CCl}_{4}$ ": buckwheat honey $(0.22 \mathrm{~g} / 10 \mathrm{~g} \mathrm{BW})$ twice daily for 11 weeks plus $\mathrm{CCl}_{4}$; mice in "silymarin $+\mathrm{CCl}_{4}$ ": silymarin $(0.5 \mathrm{mg} / 10 \mathrm{~g} \mathrm{BW})$ twice daily for 11 weeks plus $\mathrm{CCl}_{4}$.

a $54.90 \%$ increase in hepatic MDA was obtained in the $\mathrm{CCl}_{4}$-treated group relative to the control mice. Pretreatment with buckwheat honey and silymarin significantly decreased hepatic MDA levels in the $\mathrm{CCl}_{4}$-treated mice. To delineate the mechanisms underlying the protective effects of buckwheat honey, the activities of hepatic antioxidant enzymes (e.g., GSH-Px and SOD) were determined. In this study, the activities of GSH-Px and SOD in the $\mathrm{CCl}_{4}$-treated mice decreased significantly compared to those in the control mice $(P<0.05$; Figure 6(b)). SOD is a critical endogenous antioxidant enzyme that prevents and neutralizes oxidative damage [32]. GSH-Px, which has both intracellular and extracellular antioxidant functions, catalyzes the reduction of hydrogen peroxide and hydroperoxides into nontoxic products [7]. When present in excess, lipid peroxides and reactive oxygen species can easily inactivate these antioxidant enzymes [33]. Therefore, the reduction in GSH-Px and SOD was attributed to an enhanced toxicity by $\mathrm{CCl}_{4}$. Interestingly, pretreatment with buckwheat honey and silymarin significantly inhibited the decrease in GSH-Px and SOD activities induced by $\mathrm{CCl}_{4}(P<0.05)$. Meanwhile, histological observations further affirmed that administration with buckwheat honey significantly attenuates $\mathrm{CCl}_{4}$-induced liver damage.

In the present study, eight phenolic compounds were identified in buckwheat honey, of which rutin and hesperetin are the majority. Rutin has been verified to exert renalprotective effects by inhibiting ROS and antioxidant activities [34]. Hesperetin has also been confirmed to protect against oxidative stress-related hepatic dysfunction [35]. In addition to rutin and hesperetin, there are some unidentified high content antioxidants in buckwheat, which may work together in creating these antioxidative and hepatoprotective effects.

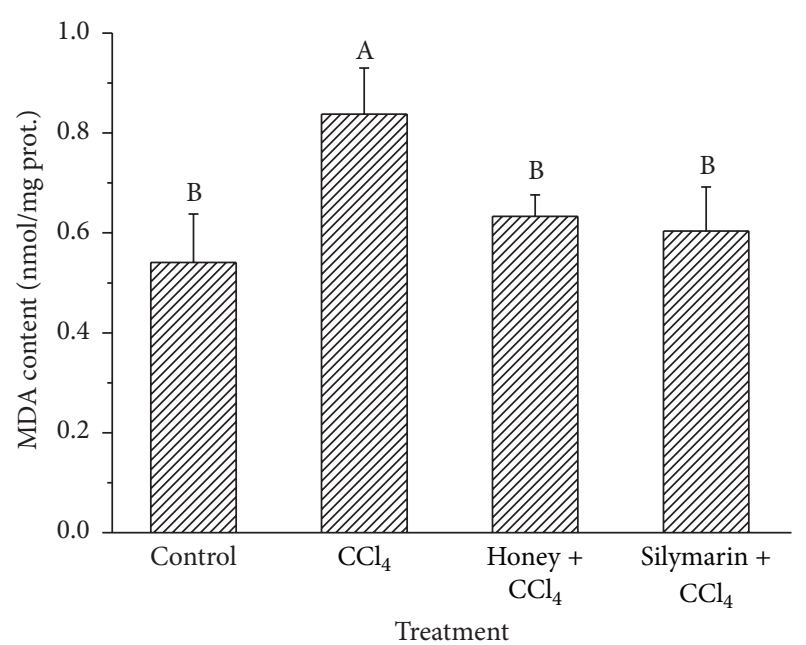

(a)

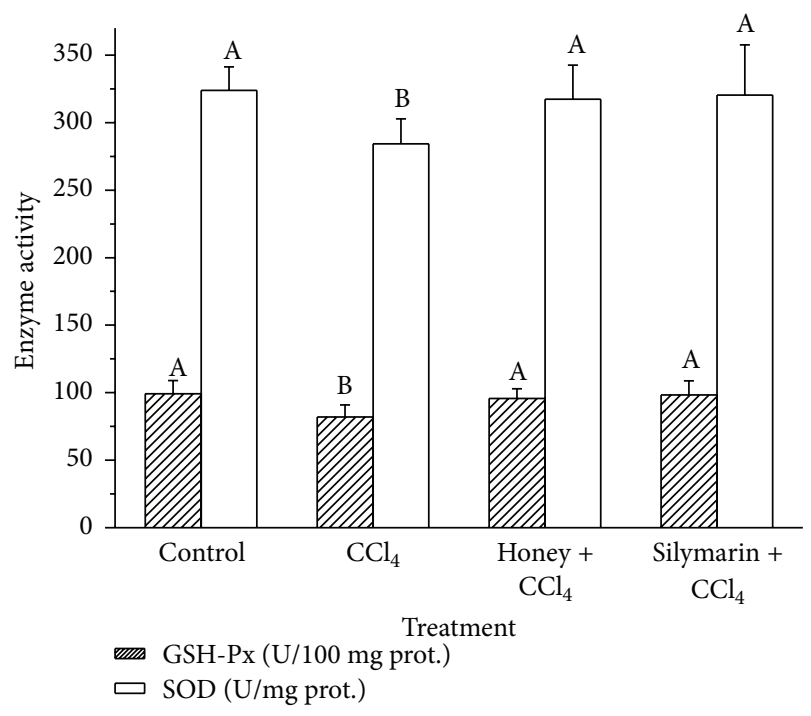

(b)

FIGURE 6: Effects of buckwheat honey on hepatic MDA content (a) and GSH-Px and SOD activities (b). Different lower case letters represent significant differences $(P<0.05)$. Mice in "control": distilled water plus peanut oil; mice in " $\mathrm{CCl}_{4}$ ": distilled water plus $\mathrm{CCl}_{4}$; mice in "honey $+\mathrm{CCl}_{4}$ ": buckwheat honey $(0.22 \mathrm{~g} / 10 \mathrm{~g} \mathrm{BW})$ twice daily for 11 weeks plus $\mathrm{CCl}_{4}$; mice in "silymarin $+\mathrm{CCl}_{4}$ ": silymarin $(0.5 \mathrm{mg} / 10 \mathrm{~g} \mathrm{BW})$ twice daily for 11 weeks plus $\mathrm{CCl}_{4}$.

Silymarin, a high antioxidative flavonoid, has been used as a drug for human liver disease induced by oxidative stress for at least two decades [36]. Usually, it is used as a positive reference in many studies [9], including in this study on oxidative stress. Caffeic acid, unidentified in this study, was found to exist in buckwheat honey [11] and have the capability of preventing nickel-induced oxidative damage in rat livers [37]. Recently, inhibition of free radical-induced damage by antioxidant supplementation has become an attractive therapeutic strategy for reducing the risk of liver disease [7]. Polyphenol extracts from natural products such as apples, Murraya koenigii L., yam peel, and bee pollen have been 


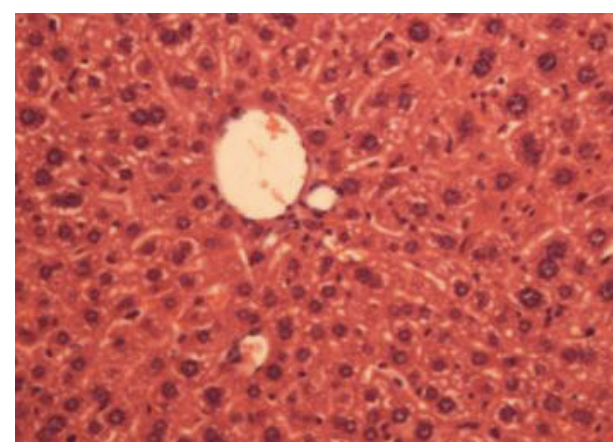

(a)

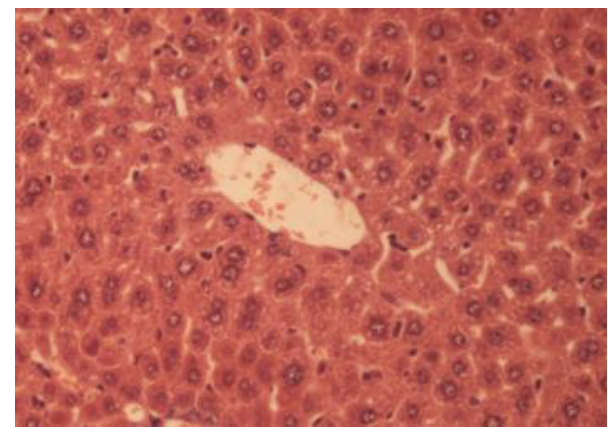

(c)

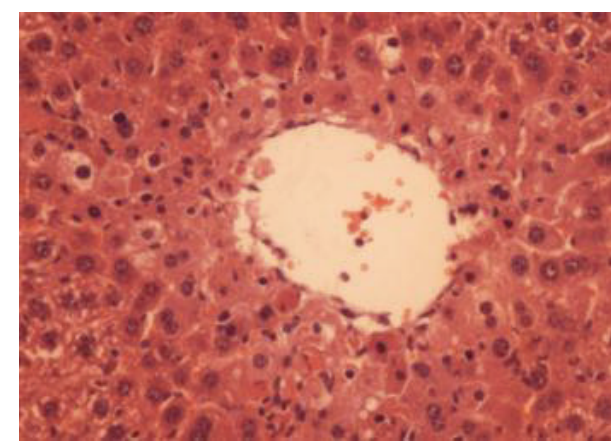

(b)

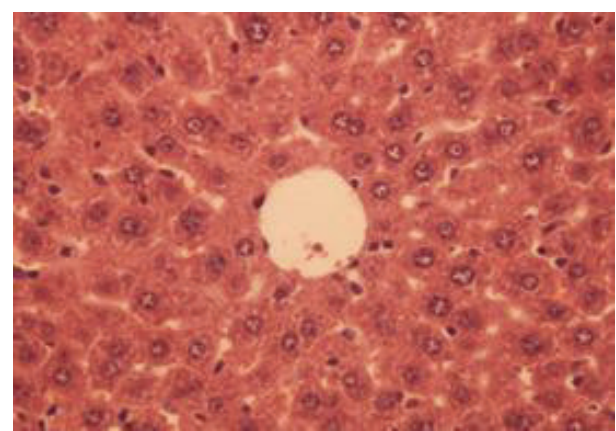

(d)

Figure 7: Effects of buckwheat honey on hepatic morphological analysis ( $\times 400 \mathrm{H \& E}$ ): control mice (a), $\mathrm{CCl}_{4}$-treated mice (b), and mice pretreated with buckwheat honey prior to $\mathrm{CCl}_{4}$ (c) and with silymarin (d).

studied for their hepatoprotective effects $[7,9,10]$. The high levels of phenolic compounds in buckwheat honey reported in previous studies [13] were confirmed in this study. Additionally, buckwheat honey has free radical scavenging and ferrous ion-chelating properties. Moreover, $\mathrm{CCl}_{4}$-induced DNA damage can be inhibited by the administration of buckwheat honey. Therefore, buckwheat honey, which has a free radical scavenging ability, reduces lipid peroxidation and increases antioxidant capacity, thereby attenuating $\mathrm{CCl}_{4}{ }^{-}$ induced liver damage in mice.

Additionally, another aim of this study was to assess whether buckwheat honey can attenuate $\mathrm{CCl}_{4}$-induced DNA damage. Lymphocyte DNA damage induced by carbon tetrachloride was assessed by alkaline single cell gel electrophoresis, that is, the comet assay. This method is a rapid and sensitive technique for measuring and analyzing DNA damage in individual cells [38]. The more severe the cell damage, the higher the amount of tail DNA. Another parameter for DNA damage analysis is OTM, which is generally considered the main index of DNA damage because it provides information about the total DNA content in the tail as well as DNA migration from the comet-head. Thus, in the present experiment, OTM is taken into consideration for the interpretation of the data [39]. In the present study, increases in tail DNA and OTM induced by $\mathrm{CCl}_{4}$ are shown in Figures 4(b) and 4(c). This demonstrated that the intraperitoneal administration of $\mathrm{CCl}_{4}$ caused a significant rise in DNA damage in peripheral lymphocytes. This result could be attributed to the in vivo action of carbon tetrachloride metabolites, that is, trichloromethyl and/or trichloromethyl peroxy radicals, which pass from the liver to the circulatory system, or to the appearance of stimulated nuclear cells in circulation. According to Kujawska et al., oxidative damage to DNA increases by $33 \%$ in mice following intraperitoneal administration of $\mathrm{CCl}_{4}$ [40]. On the other hand, Kadiiska et al. reported that $\mathrm{CCl}_{4}$ did not increase DNA damage in rat blood leukocytes [41], which may be attributed to the dose and time of $\mathrm{CCl}_{4}$ poisoning. In this study, a marked rise in tail DNA and OTM was obtained in mice treated with $\mathrm{CCl}_{4}$. More importantly, pretreatment with antioxidants can inhibit the increase of mean tail DNA and OTM. This protection should be attributed to the phenolic compound existing in buckwheat honey, which could scavenge the free radicals produced in the metabolism of $\mathrm{CCl}_{4}$ and thus attenuate the damage.

In conclusion, the results of this study demonstrated that buckwheat honey increased the antioxidant capacity and attenuated $\mathrm{CCl}_{4}$-induced liver and DNA damage in mice. Buckwheat honey demonstrated high TPC, free radical scavenging capability, and ferric-reducing antioxidant properties. Pretreatment with buckwheat honey for 10 weeks in mice significantly increased serum antioxidant activities. Therefore, buckwheat honey exhibited hepatoprotective effects in mice. Additionally, pretreatment with buckwheat honey protected DNA from $\mathrm{CCl}_{4}$-induced oxidation.

\section{Conflict of Interests}

The authors declare that there is no conflict of interests. 


\section{Acknowledgments}

This work is financially supported by the National Natural Science Foundation of China (no. 31272510) and the China Agriculture Research System (no. CARS-45-KXJ10).

\section{References}

[1] J. Medina and R. Moreno-Otero, "Pathophysiological basis for antioxidant therapy in chronic liver disease," Drugs, vol. 65, no. 17, pp. 2445-2461, 2005.

[2] R. Saller, R. Meier, and R. Brignoli, "The use of silymarin in the treatment of liver diseases," Drugs, vol. 61, no. 14, pp. 2035-2063, 2001.

[3] P. Angulo, "Medical progress: nonalcoholic fatty liver disease," The New England Journal of Medicine, vol. 346, no. 16, pp. 12211231, 2002.

[4] J. Balkan, S. Öztezcan, M. Küçük, U. Çevikbaş, N. Koçak-Toker, and M. Uysal, "The effect of betaine treatment on triglyceride levels and oxidative stress in the liver of ethanol-treated guinea pigs," Experimental and Toxicologic Pathology, vol. 55, no. 6, pp. 505-509, 2004

[5] W. J. Brattin, E. A. Glende Jr., and R. O. Recknagel, "Pathological mechanisms in carbon tetrachloride hepatotoxicity," Journal of Free Radicals in Biology and Medicine, vol. 1, no. 1, pp. 27-38, 1985.

[6] R. O. Recknagel, E. A. Glende Jr., J. A. Dolak, and R. L. Waller, "Mechanisms of carbon tetrachloride toxicity," Pharmacology \& Therapeutics, vol. 43, no. 1, pp. 139-154, 1989.

[7] J. Y. Yang, Y. Li, F. Wang, and C. Wu, "Hepatoprotective effects of apple polyphenols on $\mathrm{CCl}_{4}$-induced acute liver damage in mice," Journal of Agricultural and Food Chemistry, vol. 58, no. 10, pp. 6525-6531, 2010.

[8] Y.-H. Yeh, Y.-L. Hsieh, Y.-T. Lee, and C.-C. Hu, "Protective effects of Geloina eros extract against carbon tetrachlorideinduced hepatotoxicity in rats," Food Research International, vol. 48, no. 2, pp. 551-558, 2012.

[9] Y.-H. Yeh, Y.-L. Hsieh, and Y.-T. Lee, "Effects of yam peel extract against carbon tetrachloride-induced hepatotoxicity in rats," Journal of Agricultural and Food Chemistry, vol. 61, no. 30, pp. 7387-7396, 2013.

[10] N. Cheng, N. Ren, H. Gao, X. Lei, J. Zheng, and W. Cao, "Antioxidant and hepatoprotective effects of Schisandra chinensis pollen extract on $\mathrm{CCl}_{4}$-induced acute liver damage in mice," Food and Chemical Toxicology, vol. 55, pp. 234-240, 2013.

[11] F. Pasini, S. Gardini, G. L. Marcazzan, and M. F. Caboni, "Buckwheat honeys: screening of composition and properties," Food Chemistry, vol. 141, no. 3, pp. 2802-2811, 2013.

[12] N. Gheldof, X.-H. Wang, and N. J. Engeseth, "Buckwheat honey increases serum antioxidant capacity in humans," Journal of Agricultural and Food Chemistry, vol. 51, no. 5, pp. 1500-1505, 2003.

[13] V. R. Singelton, R. Orthifer, and R. M. Lamuela-Raventos, "Analysis of total phenols and other oxidation substrates and antioxidants by means of folin-ciocalteu reagent," Methods in Enzymology, vol. 299, pp. 152-178, 1999.

[14] Y. Liang, W. Cao, W.-J. Chen, X.-H. Xiao, and J.-B. Zheng, "Simultaneous determination of four phenolic components in citrus honey by high performance liquid chromatography using electrochemical detection," Food Chemistry, vol. 114, no. 4, pp. 1537-1541, 2009.
[15] B.-S. Wang, G.-J. Huang, H.-M. Tai, and M.-H. Huang, "Antioxidant and anti-inflammatory activities of aqueous extracts of Schizonepeta tenuifolia Briq," Food and Chemical Toxicology, vol. 50, no. 3-4, pp. 526-531, 2012.

[16] N. Singh and P. S. Rajini, "Free radical scavenging activity of an aqueous extract of potato peel," Food Chemistry, vol. 85, no. 4, pp. 611-616, 2004.

[17] I. F. F. Benzie and J. J. Strain, "The ferric reducing ability of plasma (FRAP) as a measure of 'antioxidant power': the FRAP assay," Analytical Biochemistry, vol. 239, no. 1, pp. 70-76, 1996.

[18] N. Cheng, B. Du, Y. Wang et al., "Antioxidant properties of jujube honey and its protective effects against chronic alcoholinduced liver damage in mice," Food \& Function, vol. 5, no. 5, pp. 900-908, 2014.

[19] J. Regnström, K. Ström, P. Moldeus, and J. Nilsson, “Analysis of lipoprotein diene formation in human serum exposed to copper," Free Radical Research, vol. 19, no. 4, pp. 267-278, 1993.

[20] C. Lucas-Abellán, M. T. Mercader-Ros, M. P. Zafrilla, M. I. Fortea, J. A. Gabaldón, and E. Núñez-Delicado, "ORACfluorescein assay to determine the oxygen radical absorbance capacity of resveratrol complexed in cyclodextrins," Journal of Agricultural and Food Chemistry, vol. 56, no. 6, pp. 2254-2259, 2008.

[21] N. P. Singh, M. T. McCoy, R. R. Tice, and E. L. Schneider, "A simple technique for quantitation of low levels of DNA damage in individual cells," Experimental Cell Research, vol. 175, no. 1, pp. 184-191, 1988.

[22] T.-S. Chen, S.-Y. Liou, H.-C. Wu et al., "New analytical method for investigating the antioxidant power of food extracts on the basis of their electron-donating ability: comparison to the ferric reducing/antioxidant power (FRAP) assay," Journal of Agricultural and Food Chemistry, vol. 58, no. 15, pp. 8477-8480, 2010.

[23] Y. Ruiz-Navajas, M. Viuda-Martos, J. Fernández-López, J. M. Zaldivar-Cruz, V. Kuri, and J. Á. Pérez-Álvarez, "Antioxidant activity of artisanal honey from Tabasco, Mexico," International Journal of Food Properties, vol. 14, no. 2, pp. 459-470, 2011.

[24] J. Bertoncelj, U. Doberšek, M. Jamnik, and T. Golob, "Evaluation of the phenolic content, antioxidant activity and colour of Slovenian honey," Food Chemistry, vol. 105, no. 2, pp. 822-828, 2007.

[25] I. Gülçin, "Antioxidant activity of food constituents: an overview," Archives of Toxicology, vol. 86, no. 3, pp. 345-391, 2012.

[26] P. M. Kuś, F. Congiu, D. Teper, Z. Sroka, I. Jerković, and C. I. G. Tuberoso, "Antioxidant activity, color characteristics, total phenol content and general HPLC fingerprints of six Polish unifloral honey types," LWT-Food Science and Technology, vol. 55, no. 1, pp. 124-130, 2014.

[27] B. Halliwell, "Antioxidants in human health and disease," Annual Review of Nutrition, vol. 16, pp. 33-50, 1996.

[28] E. N. Frankel, J. Kanner, J. B. German, E. Parks, and J. E. Kinsella, "Inhibition of oxidation of human low-density lipoprotein by phenolic substances in red wine," The Lancet, vol. 341, no. 8843, pp. 454-457, 1993.

[29] F. Shahidi, P. K. Janitha, and P. D. Wanasundara, "Phenolic antioxidants," Critical Reviews in Food Properties, vol. 13, pp. 657-671, 1992.

[30] B. Ou, D. Huang, M. Hampsch-Woodill, J. A. Flanagan, and E. K. Deemer, "Analysis of antioxidant activities of common vegetables employing oxygen radical absorbance capacity (ORAC) 
and ferric reducing antioxidant power (FRAP) assays: a comparative study," Journal of Agricultural and Food Chemistry, vol. 50, no. 11, pp. 3122-3128, 2002.

[31] L. W. D. Weber, M. Boll, and A. Stampfl, "Hepatotoxicity and mechanism of action of haloalkanes: carbon tetrachloride as a toxicological model," Critical Reviews in Toxicology, vol. 33, no. 2, pp. 105-136, 2003.

[32] I. N. Zelko, T. J. Mariani, and R. J. Folz, "Superoxide dismutase multigene family: a comparison of the CuZn-SOD (SOD1), Mn-SOD (SOD2), and EC-SOD (SOD3) gene structures, evolution, and expression," Free Radical Biology and Medicine, vol. 33, no. 3, pp. 337-349, 2002.

[33] Y.-S. Yang, T.-H. Ahn, J.-C. Lee et al., "Protective effects of Pycnogenol on carbon tetrachloride-induced hepatotoxicity in Sprague-Dawley rats," Food and Chemical Toxicology, vol. 46, no. 1, pp. 380-387, 2008.

[34] A. Korkmaz and D. Kolankaya, "Protective effect of rutin on the ischemia/reperfusion induced damage in rat kidney," Journal of Surgical Research, vol. 164, no. 2, pp. 309-315, 2010.

[35] L. Pari and K. Shagirtha, "Hesperetin protects against oxidative stress related hepatic dysfunction by cadmium in rats," Experimental and Toxicologic Pathology, vol. 64, no. 5, pp. 513-520, 2012.

[36] V. Kren and D. Walterová, "Silybin and silymarin-new effects and applications," Biomedical Papers of the Medical Faculty of the University Palacký, Olomouc, Czechoslovakia, vol. 149, no. 1, pp. 29-41, 2005.

[37] L. Pari and A. Prasath, "Efficacy of caffeic acid in preventing nickel induced oxidative damage in liver of rats," ChemicoBiological Interactions, vol. 173, no. 2, pp. 77-83, 2008.

[38] A. R. Collins, A. A. Oscoz, G. Brunborg et al., "The comet assay: topical issues," Mutagenesis, vol. 23, no. 3, pp. 143-151, 2008.

[39] R. R. Tice, E. Agurell, D. Anderson et al., "Single cell gel/comet assay: guidelines for in vitro and in vivo genetic toxicology testing," Environmental and Molecular Mutagenesis, vol. 35, no. 3, pp. 206-221, 2000.

[40] M. Kujawska, E. Ignatowicz, M. Murias, M. Ewertowska, K. Mikołajczyk, and J. Jodynis-Liebert, "Protective effect of red beetroot against carbon tetrachloride- and $\mathrm{N}$ nitrosodiethylamine-induced oxidative stress in rats," Journal of Agricultural and Food Chemistry, vol. 57, no. 6, pp. 2570-2575, 2009.

[41] M. B. Kadiiska, B. C. Gladen, D. D. Baird et al., "Biomarkers of oxidative stress study II. Are oxidation products of lipids, proteins, and DNA markers of $\mathrm{CCl}_{4}$ poisoning?" Free Radical Biology and Medicine, vol. 38, no. 6, pp. 698-710, 2005. 


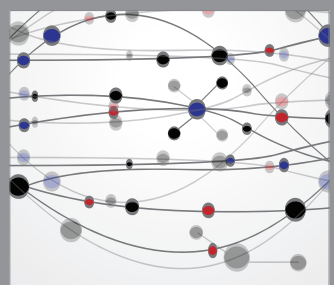

The Scientific World Journal
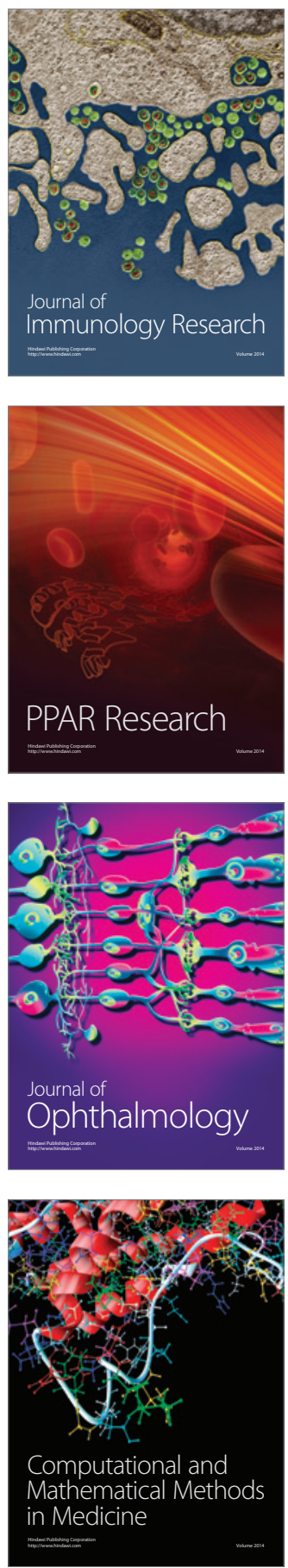

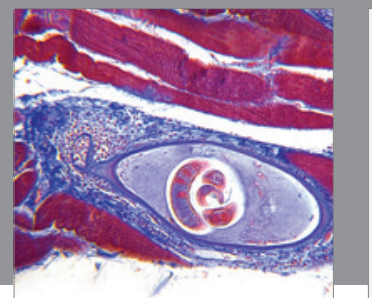

Gastroenterology

Research and Practice
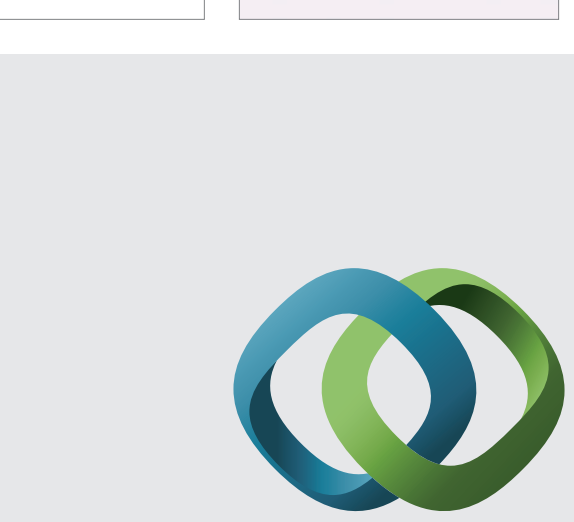

\section{Hindawi}

Submit your manuscripts at

http://www.hindawi.com
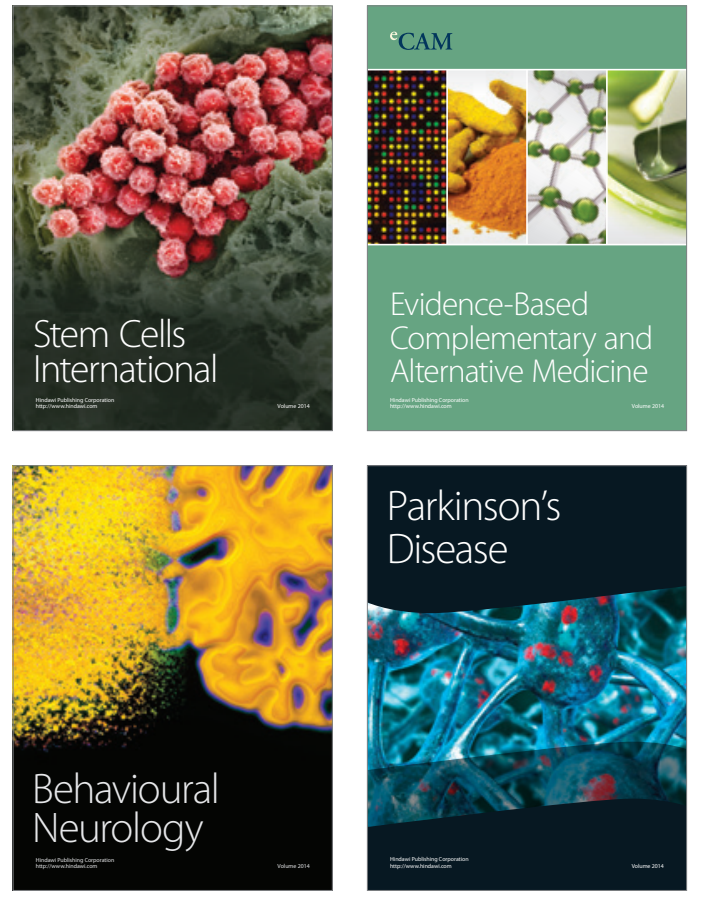
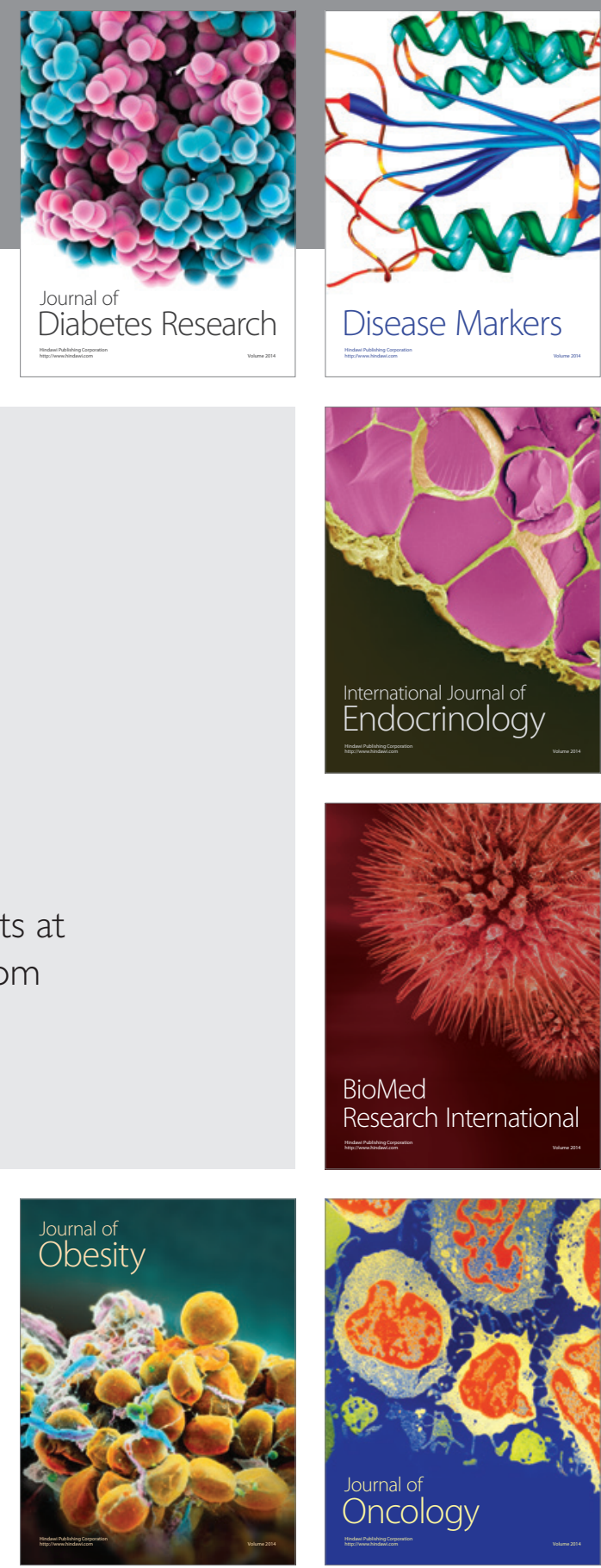

Disease Markers
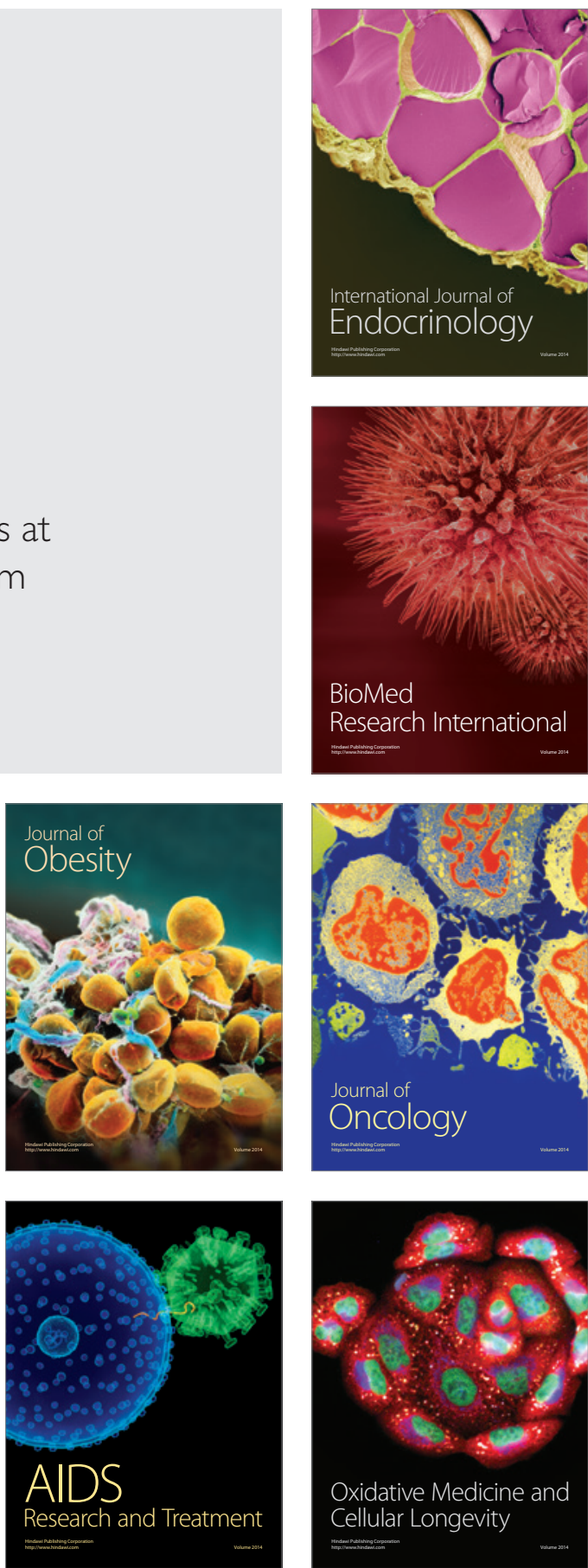